Gi respons på artikler gjennom artiklenes kommentarfelt på tidsskriftet.no.

Innleggene publiseres fortløpende på Tidsskriftets nettside og et utvalg

av innleggene publiseres også i papirutgaven i spalten «Brev til redaktøren».

Redaksjonen forbeholder seg retten til å foreta redaksjonelle endringer.

Forfattere av vitenskapelige artikler har tilsvarsrett, jf. Vancouver-gruppens regler.

Myndighetenes beslutning om massevaksinasjon under svineinfluensaen er blitt debattert på Tidsskriftets nettsider i etterkant av professor Elling Ulvestad kritiske uttalelser i portrettintervjuet «Jakten på det utenomjordiske» $i$ Tidsskriftet nr. 12/2014. Her følger to nye innlegg. Debatten kan leses i sin helhet på Tidsskriftets nettsider.

\section{Re: Jakten på det utenomjordiske}

Jeg mener det var faglig og etisk riktig å anbefale hele befolkningen å vaksinere seg. Pandemien var en reell trussel. Det var lite immunitet i befolkningen mot en sykdom som var mild for de fleste, men ville ta livet av noen, slik vi kjenner det fra flere andre sykdommer i vaksinasjonsprogrammet. Innsatsen til tusenvis av helsepersonell og tilgjengeligheten av vaksine gjorde at tilbudet ble reelt. Fire av ti fulgte anbefalingen, en høyere andel enn i de fleste av de rundt 20 vestlige land med samme anbefaling.

Jeg mistenker ikke fagfolk med et annet syn for å ha «dårlig dømmekraft». Det var større usikkerheter rundt sykdomsbyrden ved pandemien og ved vaksinen enn det er ved andre endringer i vaksinasjonsprogrammet. Ulik vekting av de ulike usikkerhetsmomentene kan prege konklusjonene. Det ville man også ha sett om usikkerhetene hadde fått en økonomisk verdi i en større samfunnsøkonomisk analyse enn den som Helsedirektoratet faktisk utførte. Det virker som om Ulvestad ikke ser at ulik vekting påvirker konklusjonene og derfor fortsetter jakten på en annen og «egentlig» grunn for anbefalingen.

Når Ulvestad ikke anerkjenner de regulatoriske ordningene for influensavaksiner, herunder bruken av surrogatmål for beskyttelse, må han nesten kreve store, etisk problematiske fase III-studier av de nye influensavaksinene før hver sesong. Disse studiene må utføres mens eventuelle nye virus sirkulerer, hvilket betyr at vaksinene ikke er tilgjengelige når de trengs. For helsemyndigheter over hele Europa var de effekt- og sikkerhetsvurderinger som det europeiske legemiddelverket gjorde før Pandemrix fikk markedsføringstillatelse, en del av grunnlaget for vaksinasjonsanbefalingen. Vurderingene bygde på kliniske utprøvinger med flere tusen deltakere. I tillegg visste beslutningstakerne at det ikke var noen nye, umiddelbare bivirkninger hos titusener av vaksinerte svensker. Å kalle Pandemrix en «uprøvd vaksine» mener jeg derfor er feil.

De som fikk vaksinen ble informert om Pandemrix' sikkerhet gjennom et faktahefte og et pakningsvedlegg for vaksinatørene og en publikumstekst $\mathrm{i}$ lang og kort versjon på helsemyndighetenes nettsider og på vaksinasjonssteder over hele landet. Tekstene pekte på usikkerhetene ved en ny vaksine som Pandemrix (1): «Eventuelle sjeldne bivirkninger kan bare oppdages ved alminnelig bruk av vaksinen i store befolkningsgrupper, og et omfattende system for å fange opp dette er etablert nasjonalt og internasjonalt.» Siden Pandemrix ble anbefalt, og ikke bare gjort tilgjengelig, erstattes skader hos de vaksinerte uten at årsakssammenheng er påvist, jf. pasientskadeloven $\S 3$.

Jeg mener ikke og har aldri uttalt at vaksinasjonskampanjen var en skandale, slik Ulvestad påstår i sitt forrige innlegg. Denne feilaktige bruken av sitater bør Ulvestad beklage. Og han bør snart presentere bevis for at helsemyndighetene ønsket å «vedlikeholde frykten i befolkningen for å fremme massevaksinasjon». Myndighetene publiserte ukentlig sine risikovurderinger, som den eksterne evalueringen kalte «gode». Det er ikke skremsel, men en del av oppgaven til åpne og demokratiske myndigheter.
Preben Aavitsland (f. 1963) er lege ved Epidemi, Kristiansand. Interessekonflikter: Aavitsland har hatt sentrale roller i Folkehelseinstituttets håndtering av svineinfluensapandemien og i instituttets egenevaluering av håndteringen.

\section{Litteratur}

1. Aavitsland $\mathrm{P}$, Blystad $\mathrm{H}$, Hauge $\mathrm{SH}$ et al. Folkehelseinstituttet under influensapandemien 2009. Delrapport: Rådgivning. Oslo: Folkehelseinstituttet, 2013. www.fhi.no/dokumenter/634b07192f.pdf (12.9.14)

\section{Re: Jakten på det utenomjordiske}

Til evalueringen av pandemien hører en evaluering av hvorfor norske helsemyndigheter gjorde motsatte vurderinger av massevaksinasjon enn danske helsemyndigheter. I ettertid ser vi at danskene tok de rette beslutningene. To naturlige spørsmål blir da: Hvorfor ble de samme data vektet så ulikt i to så like land? Og hva kan norske helsemyndigheter lære av den danske beslutningsprosessen? Jeg har ikke endelige svar på spørsmålene, men noe av svaret ligger trolig i norske helsemyndigheters neglisjering av eksplisitte kost-nytte vurderinger før massevaksinasjonen.

Jeg er enig med Aavitsland $i$ at ulik vekting av premisser kan gi ulike konklusjoner. Men for i det hele tatt å kunne vekte premisser ulikt, må det $\mathrm{i}$ forkant være gjort gode kost-nytte analyser. Med hensyn til beslutningen om massevaksinasjon er det mitt inntrykk at konklusjonen kom før vektingen, og at kost-nytte analysene derfor ble neglisjert.

Når det gjelder surrogatmål for influensavaksiners effektivitet har jeg ingen problemer med å akseptere dem, forutsatt at den som anvender målene anerkjenner svakheten ved dem. Dette kravet ble ikke innfridd da pandemivaksinen ble garantert å «beskytte mellom 70 og $100 \%$ av de vaksinerte» (1). Med hensyn til bivirkningsfrekvens, var det ikke en vel gjennomprøvd sesonginfluensavaksine folket ble tilbudt. Pandemrix var noe helt nytt, og å gjøre bruk av argumentasjon fra sesonginfluensavaksinens effektivitet og trygghet er derfor i beste fall misvisende.

Det er ellers underlig å lese at Aavitsland ber meg beklage feilaktig bruk av et sitat, all den tid jeg aldri har skrevet sitatet han mener å ha lest. Rett nok parafraserte jeg hans uttalelse om at massevaksinasjonen ga opphav til «den mest alvorlige vaksinekatastrofen i moderne tid» (2), men jeg har aldri skrevet at han mente at «vaksinasjonskampanjen var en skandale». Jeg vet godt at Aavitsland anser vaksinasjonskampanjen for å ha vært en stor suksess, og det selv om han holder massevaksinasjonen for å være en katastrofe. Jeg tar gjerne - som ham - i bruk ordet katastrofe om massevaksinasjonen, men synes skandale passer bedre.

Til slutt - Aavitsland hevder korrekt at vaksineskader i prinsippet skal kunne erstattes uten at årsakssammenheng er påvist. Det han ikke nevner er at vaksinasjonsskader kan være ekstremt vanskelige å avklare. Det var kun tilfeldigheter som gjorde at narkolepsi ble avslørt som en vaksinasjonsskade. De aller fleste som hevder å ha fått ME av Pandemrix har fått avslag av Norsk Pasientskadeerstatning, til tross for at det også er påvist sammenhenger mellom vaksinasjon og $\mathrm{ME}$. Skal disse ha håp om å vinne fram må de gå rettens vei. For mange blir det å søke erstatning derfor en utmattende, nedverdigende og ensom kamp mot et mektig byråkrati, som forholder seg mer bekvemt til et sett av regler enn til en vaksineskadd pasient.

\section{Elling Ulvestad}

elling.ulvestad@helse-bergen.no 
Elling Ulvestad (f. 1958) er professor og avdelingssjef ved Mikrobiologisk avdeling, Haukeland universitetssykehus. Ingen oppgitte interessekonflikter.

\section{Litteratur}

1. Pettersen E. Ny H1N1 bølge: Frykter 500 vil dø. www.tv2.no/nyheter/innenriks/ helse/ny-h1n1boelge-frykter-500-vil-doe-2966915.html (23.9.2014).

2. Hødnebø L. Skadene av Pandemrix var en katastrofe. nrk.no 21.1.2013. www.nrk.no/livsstil/_-en-medisinsk-katastrofe-1.10880384 (23.9.2014).

\section{Re: Sant om legemidler}

På lederplass i Tidsskriftet nr 16/2014 kommer Brænd \& Strand med en påstand jeg synes er oppsiktsvekkende (1). De skriver at det finnes informasjon om de fleste legemidler som brukes av pasienter i dag, som holdes tilbake, angivelig av aktører som utvikler legemidler: «...det finnes ukjente mengder ikke-tilgjengelig dokumentasjon om de fleste medisiner pasienter bruker i dag». Jeg vil være takknemlig om artikkelforfatterne kan oppgi referansen for denne påstanden.

\section{Espen Burum-Auensen}

espen.burum-auensen@medivir.com

Espen Burum-Auensen (f. 1976) er lege, PhD, gjesteforsker/veileder ved Akershus Universitetssykehus og Medical Affairs Manager i Medivir. Ingen oppgitte interessekonflikter.

\section{Litteratur}

1. Brænd AM, Straand J. Sant om legemidler? Tidsskr Nor Legeforen 2014; 134: 1542

\section{A.M. Brænd \& J. Straand svarer:}

Det er godt dokumentert at ikke alle resultater fra kliniske studier blir publisert (1-3). En nyere oversiktsartikkel ved Chan og medarbeidere gir flere eksempler på selektiv rapportering av medikamentstudier og betydningen av dette (4). De gir også en omfattende oversikt over publikasjonsrater beskrevet i andre artikler, som dekker ulike fagområder til ulike tider, både legemiddelstudier og andre. Lehman og Loder oppsummerer i en lederartikkel i BMJ flere artikler som omhandler manglende data fra kliniske studier, og nevner hvordan det å lete etter upubliserte data fra kliniske studier gjennomført før obligatorisk registrering av studier vil være nærmest umulig (5). Medisiner som er i bruk i dag har ofte blitt introdusert på markedet for flere år, kanskje tiår, siden. Så lenge det fortsatt ikke er slik at alle data fra kliniske studier er offentlig tilgjengelige, vil det være ukjent hvor mye dokumentasjon som finnes, men som ikke synes.

\section{Anja Maria Brænd \\ ambraend@medisin.uio.no \\ Jørund Straand}

Anja Maria Brænd (f. 1980) er lege og ph.d.-stipendiat ved Avdeling for allmennmedisin, Universitetet i Oslo.

Ingen oppgitte interessekonflikter

Jørund Straand (f. 1951) er professor i allmennmedisin og avdelingsleder ved Avdeling for allmennmedisin, Universitetet i Oslo.

Ingen oppgitte interessekonflikter.

\section{Litteratur}

1. Jones CW, Handler L, Crowell KE et al. Non-publication of large randomized clinical trials: cross sectional analysis. BMJ 2013; 347 (oct28 9): $f 6104$

2. Rising K, Bacchetti $P$, Bero L. Reporting bias in drug trials submitted to the Food and Drug Administration: review of publication and presentation. PLoS Med 2008: 5: e217, discussion e217.

3. Gibson LM, Brazzelli M, Thomas BM et al. A systematic review of clinical trials of pharmacological interventions for acute ischaemic stroke (1955-2008) that were completed, but not published in full. Trials 2010; 11: 43

4. Chan AW, Song F, Vickers A et al. Increasing value and reducing waste: addressing inaccessible research. Lancet 2014: 383: 257-66.

5. Lehman R, Loder E. Missing clinical trial data. BMJ 2012; 344 (jan03 1): d8158.

\section{Re: Å overbringe en vond beskjed}

Det er med tungt hjerte jeg leser om nok et eksempel på klønete kommunikasjon i en vanskelig situasjon, denne gangen observert av en medpasient og beskrevet som en «personlig opplevelse» i Tidsskriftet (1). Jo mer alvor i budskapet, jo mer klønete blir vi leger. Armene blir lengre. Øynene viker vekk, og vi blir stående ved sengen så vi kan rømme fort ut av døren. Skulle ønske jeg også hadde en slik historie å fortelle. Som presten som selv tok grep (1).

For jeg har vært vitne til så dårlig kommunikasjon av kolleger $i$ alvorlige stunder at jeg har hatt lyst til å gripe inn. Eller rømme, eventuelt grave meg ned gjennom linoleumen. Men jeg så sikkert bare ned, flyktet vekk med øynene, og kroppen - og forbannet meg på at jeg aldri skulle være like klønete og feig. Men det har jeg sikkert vært.

Det letteste er å sette i gang å snakke. Fort, lenge og med mange vanskelige ord som er trygge. Alle de vante ordene kommer lett. Men ikke de aller vondeste, men viktigste. «Jeg beklager å måtte fortelle deg at prøvene av kulen viser at du har kreft». Lett å skrive, mye vanskeligere å si. Celleforandringer, umodne celler, tumor, til og med svulst, er nok lettere å si enn det ene ordet. Det som har svidd seg fast i angsten hos pasienten helt siden de bestilte legetimen. Kreft. Man trenger ikke si mer. De får ikke med seg mer den dagen.

Det er skrevet artikler om det, bøker. Det finnes en slags oppskrift. Gi et varsel om hva som kommer, si det rett ut - så stopp og se hva som skjer. Men for å klare det, må man orke å snakke med pasienten. Tørre å stoppe opp. Ta inn reaksjonen. Tåle gråten, tåle sinnet. Tåle å ikke kunne løse problemet. Ikke vite fasiten. Vi kommer til kort medisinsk, men det er da våre to viktigste etiske regler må brukes. Ofte lindre - ALLTID trøste.

Jo da, Øyvind Ekeberg har rett $\mathrm{i}$ at vi på medisinstudiet i Oslo fikk opplæring i dette (2). Tilbudet var der. Undervisningen var veldig god også. De arrangerte et seminar der innleide skuespillere skulle være pasient, som fikk triste nyheter av oss som spilte leger. Skuespillerne skulle demonstrere ulike former for normale reaksjoner. Vi skulle ha rollespill med tilbakemelding fra gruppen. Skummelt for enhver - utålelig for en legestudent som har beskyttet seg selv mot å stå på tynn is hele oppveksten. Som har sørget for å vite alle svarene. Her var beskjeden klar. «Du får ikke snakke teknisk komplisert fag. Her handler det kun om pasientens respons, og dine egne reaksjoner.»

Utålelig. Utenkelig. Så umulig at kun $30 \%$ av kullet møtte opp. Til ett av de viktigste seminarene på hele studiet.

\section{Elisabeth Holmboe Eggen}

elisabeteggen@gmail.com

Elisabeth Holmboe Eggen (f. 1974) er lege i spesialisering og programleder for barne-TV.

Ingen oppgitte interessekonflikter.

Litteratur

1. Onshuus K. Å overbringe en vond beskjed. Tidsskr Nor Legeforen 2014; 134 : 1587.

2. Ekeberg O. Krevende kommunikasjon. Tidsskr Nor Legeforen 2014; 134: 1588.

\section{Re: Myteknuserne}

Interessant nok er medisinsk redaktør Are Brean ute i et vitenskapsfilosofisk ærend i innledningen til lederen «Myteknuserne» i Tidsskriftet nr 17/2014 (1). Men det glipper. Han skriver at «som leger bekjenner vi oss til et naturvitenskapelig paradigme, der enhver påstand må testes rasjonelt og empirisk før den kan aksepteres som sann». Men den kliniske virkeligheten er «møkkete» skriver han, «gjennomsnittspasienten finnes ikke, symptomer er vanskelige å tolke og behandlingseffekter påvirkes av forhold vi ikke har oversikt over eller kontroll på.»)

Dette fortolker jeg som polemisk positivisme (2). Jeg trodde det 